\title{
Nitrogen Uptake Efficiency of Olive Cultivars
}

\author{
Ricardo Fernández-Escobar *, Felisa Antonaya-Baena and Sergio Almeida-Lavado
}

Departamento de Agronomía, Escuela Técnica Superior de Ingeniería Agronómica y de Montes, Universidad de Córdoba, 14071 Córdoba, Spain; mfeliab@hotmail.com (F.A.-B.); sergio.almeida-lavado@gmail.com (S.A.-L.)

* Correspondence: rfernandez-escobar@uco.es

Citation: Fernández-Escobar, R.;

Antonaya-Baena, F.; Almeida-Lavado, S. Nitrogen Uptake Efficiency of Olive Cultivars. Horticulturae 2021, 7, 136. https://doi.org/10.3390/ horticulturae7060136

Academic Editors: Douglas D. Archbold and Wilfried Rozhon

Received: 17 April 2021

Accepted: 4 June 2021

Published: 6 June 2021

Publisher's Note: MDPI stays neutral with regard to jurisdictional claims in published maps and institutional affiliations.

Copyright: (c) 2021 by the authors. Licensee MDPI, Basel, Switzerland. This article is an open access article distributed under the terms and conditions of the Creative Commons Attribution (CC BY) license (https:// creativecommons.org/licenses/by/ $4.0 /)$.
Abstract: Maximizing nitrogen uptake efficiency is a sustainable objective to reduce the amount of nitrogen fertilizers applied in olive orchards. Many factors affect this parameter, but nothing is known about whether there are differences among cultivars related to nitrogen uptake efficiency in the olive, and if there are interactions with soil type. To clarify these questions, two groups of experiments were conducted. In the first group, four experiments were carried out in which 20 olive cultivars were compared. In the second group, three experiments were carried out to study the interaction with the type of soil. In all experiments, mist-rooted olive cuttings were growing in $1.1 \mathrm{~L}$ pots containing a mixture of sand and peat (2:1 by volume). Depending on the experiment, plants were placed in a shadehouse or in growth chambers at $25 / 15^{\circ} \mathrm{C}$ (day/night) with a $14 \mathrm{~h}$ photoperiod and $70 \%$ humidity. Plants received weekly applications of $100 \mathrm{ppm} \mathrm{N}$ throughout the irrigation water, alternating with one or two applications of $150 \mathrm{~mL}$ of tap water. Some plants of each cultivar did not receive nitrogen and served as a control for NUE calculation. A nutrient solution without nitrogen was applied every four weeks to prevent nutritional deficiencies. Results indicated that there are differences among cultivars in the efficiency of uptake nitrogen. The Spanish cultivars 'Picual', 'Arbequina' and 'Manzanilla de Sevilla', together with the Greek cultivar 'Koroneiki' and the Italian 'Frantoio', were the cultivars with high NUE in this work. Soil type did not affect NUE, and no interaction between soil type and cultivar was observed.

Keywords: Olea europaea; olive nutrition; nitrogen over-fertilization

\section{Introduction}

Despite the large amount of scientific literature indicating the negative effects on crop yield and quality, and on the environment, of an excess of nitrogen application in many crops [1-4], including the olive [5-7], nitrogen overfertilization is still usual in many fertilization programs. The perception that an increase in nitrogen fertilization may ensure high yields, together with the relatively low cost of nitrogen fertilizers, leads to the application of nitrogen in excess of plant needs for optimum yield.

From a scientific and technological point of view, agricultural practices should be carried out under the criteria that encourage sustainability. In this sense, a more responsible use of fertilizers is required. In fruit tree orchards, nitrogen, as well as other mineral nutrients, should be applied only when there are proofs that it is needed to assure a normal growth and productivity, and when an economic response to nitrogen application is expected. The best strategy to optimize nitrogen fertilization in fruit tree orchards is the application of nitrogen when the previous season's leaf analyses indicates that leaf nitrogen concentration is below the deficiency threshold [8-10]. Another question is how to maximize the fertilization practice when leaf analysis indicates the need for fertilization. Nitrogen uptake efficiency (NUE) is the amount of nitrogen recovered by the tree related to the total amount of fertilizer nitrogen applied. Timing of nitrogen application, form of fertilizer application, the presence of nitrogen in the soil or in the irrigation water, the amount of fertilizer nitrogen applied, the nutritional status of the plants, and other 
factors affect NUE [1,11]. In herbaceous plants, there is evidence of genetic variation among cultivars related to NUE [12]. The authors of [13] found differences between citrus rootstocks. These evidences suggest that one approach to reduce nitrogen use in crop production is the development of new cultivars with high NUE as described above, or with high nitrogen use efficiency, sometimes defined as the increase in biomass per unit of nitrogen content in the plant $[3,4,14]$. The objective of the present work was to evaluate if there are differences among olive cultivars in nitrogen uptake efficiency, and the possible interaction with soil type.

\section{Materials and Methods}

\subsection{Experimental Design and Plant Measurements}

Two groups of experiments were conducted. In all experiments, mist-rooted olive cuttings were growing in $1.1 \mathrm{~L}$ pots containing a mixture of sand and peat (2:1 by volume). Depending on the time of year in which the experiments were developed, the plants were placed in a shadehouse located in the experimental farm of Campus de Rabanales, University of Córdoba, Spain (experiments $1,3,5$ and 6), or in growth chambers at $25 / 15^{\circ} \mathrm{C}$ (day/night) with a $14 \mathrm{~h}$ photoperiod and $70 \%$ humidity (experiments 2,4 and 7 ). Plants were pruned to a single shoot and watered once or more times a week, depending upon plant needs, with $150 \mathrm{~mL}$ water per pot during an acclimation period of 30 days.

In the first group, four different experiments were developed with a total of 20 olive cultivars. The experiments were arranged in a randomized complete block design with seven to eight treatments, depending on the number of cultivars used in each experiment, and ten replications. During the development of the experiments, plants received weekly applications of $100 \mathrm{ppm} \mathrm{N}$ throughout the irrigation water, alternating with one or two applications of $150 \mathrm{~mL}$ of tap water, depending on plant requirements. Ten plants of each cultivar, the same number of plants of each cultivar which received the treatment, did not receive nitrogen and served as a control for NUE calculation. Urea $(46 \% \mathrm{~N})$ was used as nitrogen source. A nutrient solution without nitrogen was applied every four weeks to prevent nutritional deficiencies. This solution was composed of: $2 \mathrm{mM} \mathrm{MgSO}_{4}, 1 \mathrm{mM}$ $\mathrm{KH}_{2} \mathrm{PO}_{4}, 20 \mu \mathrm{M}$ Fe-ethylenediamine-di-o-hy-drosyphenylacetic acid, $5 \mathrm{mM} \mathrm{CaCl}_{2}, 5 \mathrm{mM}$ $\mathrm{KCl}, 12.5 \mu \mathrm{M} \mathrm{H}_{3} \mathrm{BO}_{3}, 0.2 \mu \mathrm{M}\left(\mathrm{NH}_{4}\right)_{6} \mathrm{Mo}_{7} \mathrm{O}_{24} 4 \mathrm{H}_{2} \mathrm{O}, 1 \mu \mathrm{M} \mathrm{MnSO}_{4} \mathrm{H}_{2} \mathrm{O}, 1 \mu \mathrm{M} \mathrm{ZnSO}_{4} 7 \mathrm{H}_{2} \mathrm{O}$ and $0.25 \mu \mathrm{M} \mathrm{CuSO}_{4} 5 \mathrm{H}_{2} \mathrm{O}$.

The second group of experiments were established to study the interaction with the type of soil. For this purpose, three different experiments were carried out. In this second group, the experiments were arranged in a randomized factorial design with two factors (cultivar and soil) and eight replications. The cultivars were 'Picual', 'Arbequina', 'Frantoio' and 'Sikitita'. In the first experiment only 'Picual' and 'Arbequina' were used. The soils included in all the experiments represent the soils where many olive trees are grown in southern Spain. Samples taken from the upper layer of these soils were used for the experiments. One sample was taken from fluvial deposits of the Guadalquivir river $\left(37^{\circ} 51^{\prime} 13^{\prime \prime} \mathrm{N} ; 4^{\circ} 48^{\prime} 14^{\prime \prime} \mathrm{W}\right.$; altitude: $\left.94 \mathrm{~m}\right)$. It is a loam soil with a cation exchange capacity (CEC) of $17.39 \mathrm{meq} / 100 \mathrm{~g}$, a basic $\mathrm{pH}(8.34)$ and low content of carbonates (14.59\%). The second sample was taken from Guadalquivir's terraces ( $37^{\circ} 51^{\prime} 13^{\prime \prime} \mathrm{N} ; 4^{\circ} 48^{\prime} 14^{\prime \prime} \mathrm{W}$; altitude: $94 \mathrm{~m}$ ). It is a sandy-loam soil with a cation exchange capacity (CEC) of $10.22 \mathrm{meq} / 100 \mathrm{~g}$, a neutral $\mathrm{pH}$ (6.9) and very low content of carbonates (almost $0 \%$ ). The third sample was taken from a traditional area of olive tree cultivation in Granada province $\left(37^{\circ} 6^{\prime} 4^{\prime \prime} \mathrm{N}\right.$; $3^{\circ} 51^{\prime} 9^{\prime \prime} \mathrm{W}$; altitude: $853 \mathrm{~m}$ ). It is a loam soil with a cation exchange capacity (CEC) of $15.87 \mathrm{meq} / 100 \mathrm{~g}$, a basic $\mathrm{pH}(8.31)$ and high content in carbonates $(83.76 \%)$.

The experiments lasted for 11 weeks except for experiments 3 and 6 which lasted 14 weeks. During this time shoot length was measured weekly to determine the evolution of vegetative growth for each cultivar. 


\subsection{Nitrogen Determination}

At the end of each experiment plants were harvested and leaves, stems and roots were removed separately from each plant, washed on distilled water, dried at $80^{\circ} \mathrm{C}$ for $72 \mathrm{~h}$, ground and stored in an oven at $60{ }^{\circ} \mathrm{C}$ until analysis. Nitrogen was determined with a EuroVector EA3000 CHN analyser by the Dumas procedure [15].

Nitrogen uptake efficiency (NUE) was estimated according to the following formula:

$$
\mathrm{NUE}=(\mathrm{N} \text { uptake } / \mathrm{N} \text { applied }) \times 100 .
$$

where $\mathrm{N}$ uptake $=$ Nitrogen in total plant-Nitrogen in plant with $0 \mathrm{ppm} \mathrm{N}$.

$\mathrm{N}$ applied $=$ Nitrogen applied as fertilizer

\subsection{Statistical Analyses}

Analyses of variance were performed on the data using the statistical program "Statistic" version 9.0 (Analytical Software, Tallahassee, FL, USA). All percentage values were transformed using the arc sin of the square root before analysis. Where a significant $\mathrm{F}$ was observed, mean separation between treatments was obtained by Tukey's test.

\section{Results}

There were significant differences among cultivars in vegetative growth, as expected since olive cultivars exhibit different vigour (Table 1). There were also differences in shoot growth between experiments for the same cultivar. This is not exceptional because the initial plant vigour and the environmental conditions of the experiments were also different. However, it should be noted the highest variability found in experiment 3, expressed by the highest coefficient of variation. In this experiment shoot growth was lower than in the other experiments, probably due because the initial size of the plants was also lower.

Total plant nitrogen content, obtained by the sum of nitrogen content in leaves, stems and roots, is showed in Table 2. There were significant differences among cultivars. There were differences between experiment 3 and the other experiments, because in this experiment the plants were smaller, as indicated above. Considering all the experiments, 'Koroneiki', 'Frantoio' and 'Arbosana' seems to be the cultivars that accumulate more nitrogen, followed by 'Picual', 'Arbequina', 'Cobrançosa' and 'Manzanilla de Sevilla'. Most of these cultivars also showed the higher NUE (Table 3). For this parameter, 'Koroneiki', 'Picual' and 'Arbosana' were the most efficient followed by 'Arbequina', 'Frantoio', 'Manzanilla de Sevilla' and 'Sikitita'.

Except for experiment 3, in which the plants exhibited very short vegetative growth compared to the other experiments, there were no relationships between plant vigour and nitrogen content or nitrogen uptake efficiency (Table 4). On the other hand, the relationship between nitrogen content per plant and nitrogen uptake efficiency is not clear, because the correlation between both variables was significant only in two of the four experiments.

No interactions were obtained between soil type and cultivars in vegetative growth of olive plants, except for experiment 7 which showed the highest variability, expressed by the coefficient of variation (Table 5). This interaction was found only because 'Picual' plants grew less in the substrate from Guadalquivir's terraces than in other substrates (data not shown). In this experiment, substrates from Granada province significantly reduces plant growth related to the other soil types. No significant differences were found between cultivars in the other experiments. Nitrogen uptake efficiency was unaffected by soil type or the interaction with olive cultivars (Table 6). In experiment 7 there were cultivar differences, in the sense that 'Sikitita' was more efficient than 'Frantoio', an effect that was not observed in experiment 6 . 
Table 1. Vegetative growth of 20 olive cultivars at the end of the experiments in response to $100 \mathrm{ppm}$ $\mathrm{N}$ application.

\begin{tabular}{|c|c|c|c|c|}
\hline \multicolumn{5}{|c|}{ Shoot Length $(\mathrm{cm})^{1}$} \\
\hline Cultivar & Exp. 1 & Exp. 2 & Exp. 3 & Exp. 4 \\
\hline 'Arbequina' & $45.4 \mathrm{~b}$ & $24.8 \mathrm{~b}$ & & $20.9 \mathrm{~b}$ \\
\hline 'Arbosana' & & $28.5 \mathrm{~b}$ & $4.58 \mathrm{bcd}$ & $6.95 \mathrm{c}$ \\
\hline 'CobranÇosa' & & $26.8 \mathrm{~b}$ & & $18.8 \mathrm{bc}$ \\
\hline 'Coratina' & & & & $21.3 \mathrm{~b}$ \\
\hline 'Cornicabra' & & & $6.58 \mathrm{bcd}$ & \\
\hline 'Empeltre' & & & $2.50 \mathrm{~cd}$ & \\
\hline 'Farga' & & & & $14.6 \mathrm{bc}$ \\
\hline 'Frantoio' & $37.9 \mathrm{~b}$ & & $12.8 \mathrm{ab}$ & \\
\hline 'Hojiblanca' & $58.2 \mathrm{a}$ & & & \\
\hline 'Koroneiki' & $65.2 \mathrm{a}$ & & $11.4 \mathrm{abc}$ & \\
\hline 'Lechín de Granada' & & & & $15.6 \mathrm{bc}$ \\
\hline 'Lechín de Sevilla' & & $41.6 \mathrm{a}$ & & \\
\hline 'Manzanilla cacereña' & & & & $33.6 \mathrm{a}$ \\
\hline 'Manzanilla de Sevilla' & & $23.7 b$ & $2.58 \mathrm{~d}$ & \\
\hline 'Manzanillo cordobés' & $37.8 \mathrm{~b}$ & & & \\
\hline 'Nevadillo fino' & $41.6 \mathrm{~b}$ & & & \\
\hline 'Ocal' & & $25.9 \mathrm{~b}$ & & \\
\hline 'Picholine marrocaine' & & & $4.20 \mathrm{~cd}$ & \\
\hline 'Picual' & $45.5 \mathrm{~b}$ & $30.1 \mathrm{~b}$ & $5.69 \mathrm{bcd}$ & \\
\hline 'Sikitita' & $37.9 \mathrm{~b}$ & & $17.9 \mathrm{a}$ & \\
\hline $\mathrm{CV}(\%)^{2}$ & 8.7 & 20.5 & 36.3 & 12.1 \\
\hline
\end{tabular}

${ }^{1}$ Means within columns followed by different letters are significantly different at $p \leq 0.05$ by Tukey's test.

${ }^{2}$ Coefficient of variation.

Table 2. Total nitrogen content in plants of 20 olive cultivars in response to $100 \mathrm{ppm} \mathrm{N}$ application.

\begin{tabular}{|c|c|c|c|c|}
\hline \multicolumn{5}{|c|}{ N Content (mg) ${ }^{1}$} \\
\hline Cultivar & Exp. 1 & Exp. 2 & Exp. 3 & Exp. 4 \\
\hline 'Arbequina' & 197.2 bc & $152.7 \mathrm{bcd}$ & & $130.8 \mathrm{a}$ \\
\hline 'Arbosana' & & $179.8 \mathrm{ab}$ & $88.3 \mathrm{a}$ & $104.7 \mathrm{abc}$ \\
\hline 'CobranÇosa' & & $150.2 \mathrm{~cd}$ & & $116.9 \mathrm{ab}$ \\
\hline 'Coratina' & & & & $97.4 \mathrm{abc}$ \\
\hline 'Cornicabra' & & & $40.7 \mathrm{~b}$ & \\
\hline 'Empeltre' & & & $38.2 \mathrm{~b}$ & \\
\hline 'Farga' & & & & $70.1 \mathrm{c}$ \\
\hline 'Frantoio' & $233.2 \mathrm{a}$ & & $83.6 \mathrm{a}$ & \\
\hline 'Hojiblanca' & $167.5 \mathrm{~cd}$ & & & \\
\hline 'Koroneiki' & $222.4 \mathrm{ab}$ & & $90.5 \mathrm{a}$ & \\
\hline 'Lechín de Granada' & & & & $77.4 \mathrm{bc}$ \\
\hline 'Lechín de Sevilla' & & $172.3 \mathrm{abc}$ & & \\
\hline 'Manzanilla cacereña' & & & & $112.8 \mathrm{ab}$ \\
\hline 'Manzanilla de Sevilla' & & $156.3 \mathrm{bcd}$ & $52.8 \mathrm{~b}$ & \\
\hline 'Manzanillo cordobés' & $221.4 \mathrm{ab}$ & & & \\
\hline 'Nevadillo fino' & $213.3 \mathrm{ab}$ & & & \\
\hline 'Ocal' & & $137.3 \mathrm{~d}$ & & \\
\hline 'Picholine marrocaine' & & & $32.4 \mathrm{~b}$ & \\
\hline 'Picual' & $215.7 \mathrm{ab}$ & $184.6 \mathrm{a}$ & $48.3 \mathrm{~b}$ & \\
\hline 'Sikitita' & $146.5 \mathrm{~d}$ & & $86.2 \mathrm{a}$ & \\
\hline$C V(\%)^{2}$ & 2.22 & 11.0 & 6.31 & 12.2 \\
\hline
\end{tabular}

${ }^{1}$ Means within columns followed by different letters are significantly different at $p \leq 0.001$ by Tukey's test.

${ }^{2}$ Coefficient of variation. 
Table 3. Nitrogen uptake efficiency of 20 olive cultivars.

\begin{tabular}{|c|c|c|c|c|}
\hline \multicolumn{5}{|c|}{ NUE (\%) ${ }^{1}$} \\
\hline Cultivar & Exp. 1 & Exp. 2 & Exp. 3 & Exp. 4 \\
\hline 'Arbequina' & $52.4 \mathrm{~b}$ & $72.1 \mathrm{ab}$ & & $58.4 \mathrm{a}$ \\
\hline 'Arbosana' & & $66.1 \mathrm{ab}$ & $30.7 \mathrm{abc}$ & $27.7 \mathrm{ab}$ \\
\hline 'CobranÇosa' & & $42.7 \mathrm{~b}$ & & $22.8 \mathrm{~b}$ \\
\hline 'Coratina' & & & & $31.7 \mathrm{ab}$ \\
\hline 'Cornicabra' & & & $13.7 \mathrm{bc}$ & \\
\hline 'Empeltre' & & & $14.4 \mathrm{bc}$ & \\
\hline 'Farga' & & & & $28.9 \mathrm{ab}$ \\
\hline 'Frantoio' & $86.9 \mathrm{a}$ & & $22.1 \mathrm{bc}$ & \\
\hline 'Hojiblanca' & $51.9 \mathrm{~b}$ & & & \\
\hline 'Koroneiki' & $69.1 \mathrm{ab}$ & & $32.2 \mathrm{ab}$ & \\
\hline 'Lechín de Granada' & & & & $4.2 \mathrm{~b}$ \\
\hline 'Lechín de Sevilla' & & $66.6 \mathrm{ab}$ & & \\
\hline 'Manzanilla cacereña' & & & & $36.0 \mathrm{ab}$ \\
\hline 'Manzanilla de Sevilla' & & $82.8 \mathrm{a}$ & $15.7 \mathrm{bc}$ & \\
\hline 'Manzanillo cordobés' & $68.5 \mathrm{ab}$ & & & \\
\hline 'Nevadillo fino' & $68.5 \mathrm{ab}$ & & & \\
\hline 'Ocal' & & $55.4 \mathrm{ab}$ & & \\
\hline 'Picholine marrocaine' & & & $9.6 \mathrm{c}$ & \\
\hline 'Picual' & $66.9 \mathrm{ab}$ & $84.4 \mathrm{a}$ & $26.0 \mathrm{abc}$ & \\
\hline 'Sikitita' & $42.9 \mathrm{~b}$ & & $43.4 \mathrm{a}$ & \\
\hline Significance & $p \leq 0.05$ & $p \leq 0.01$ & $p \leq 0.001$ & $p \leq 0.05$ \\
\hline $\mathrm{CV}(\%)^{2}$ & 30.2 & 24.3 & 30.6 & 29.3 \\
\hline
\end{tabular}

${ }^{1}$ Means within columns followed by different letters are significantly different by Tukey's test. ${ }^{2}$ Coefficient of variation.

Table 4. Coefficients of linear correlations between cultivar vigour, $\mathrm{N}$ uptake efficiency and $\mathrm{N}$ content/plant.

\begin{tabular}{ccccc}
\hline \multicolumn{5}{c}{ r Value $^{\mathbf{1}}$} \\
\hline & Exp. 1 & Exp. 2 & Exp. 3 & Exp. 4 \\
\hline Vigour vs. N content & $-0.02^{\mathrm{NS}}$ & $0.50^{\mathrm{NS}}$ & $0.68^{*}$ & $0.37^{\mathrm{NS}}$ \\
Vigour vs. NUE & $-0.12^{\mathrm{NS}}$ & $-0.002^{\mathrm{NS}}$ & $0.75^{*}$ & $0.34^{\mathrm{NS}}$ \\
NUE vs. N content & $0.91^{* *}$ & $0.53^{\mathrm{NS}}$ & $0.83^{* *}$ & $0.68^{\mathrm{NS}}$ \\
\hline
\end{tabular}

${ }^{1} \mathrm{NS},{ }^{*}, * *$ Non significant or significant at $p \leq 0.05$ or $p \leq 0.01$, respectively.

Table 5. Vegetative growth of olive cultivars growing in different soils.

\begin{tabular}{cccc}
\hline & \multicolumn{3}{c}{ Shoot Length (cm) $^{\mathbf{1}}$} \\
\cline { 2 - 4 } & Exp. 5 & Exp. 6 & Exp. 7 \\
\hline Soil type & & & \\
\hline Fluvial deposits & $32.5 \mathrm{a}$ & $57.4 \mathrm{a}$ & $75.2 \mathrm{a}$ \\
Guadalquivir's terraces & $34.7 \mathrm{a}$ & $55.9 \mathrm{a}$ & $73.0 \mathrm{a}$ \\
Granada province & $24.2 \mathrm{a}$ & $51.5 \mathrm{a}$ & $48.0 \mathrm{~b}$ \\
\hline Cultivar & & & \\
\hline 'Picual' & $25.5 \mathrm{a}$ & $56.9 \mathrm{a}$ & $78.9 \mathrm{~b}$ \\
'Arbequina' & $33.8 \mathrm{a}$ & $55.9 \mathrm{a}$ & $65.0 \mathrm{a}$ \\
'Frantoio' & - & $57.3 \mathrm{a}$ & $70.6 \mathrm{a}$ \\
\hline 'Sikitita' & - & $49.6 \mathrm{a}$ & $*$ \\
\hline Interaction soil x cultivar ${ }^{2}$ & NS & NS & 28.9 \\
\hline CV (\%) ${ }^{3}$ & - & 3.87 &
\end{tabular}

${ }^{1}$ Means within columns and factors followed by different letters are significantly different at $p \leq 0.001$ by Tukey's test. ${ }^{2} \mathrm{NS},{ }^{*}$ Non significant or significant at $p \leq 0.05,{ }^{3}$ Coefficient of variation. 
Table 6. Nitrogen uptake efficiency of olive cultivars growing in different soils.

\begin{tabular}{|c|c|c|c|}
\hline & \multicolumn{3}{|c|}{ NUE $(\%)^{1}$} \\
\hline & Exp. 5 & Exp. 6 & Exp. 7 \\
\hline \multicolumn{4}{|l|}{ Soil type } \\
\hline Fluvial deposits & $56.0 \mathrm{a}$ & $21.3 \mathrm{a}$ & $76.9 \mathrm{a}$ \\
\hline Guadalquivir's terraces & $53.1 \mathrm{a}$ & $31.6 \mathrm{a}$ & $70.7 \mathrm{a}$ \\
\hline Granada province & $45.6 \mathrm{a}$ & $31.0 \mathrm{a}$ & $60.7 \mathrm{a}$ \\
\hline \multicolumn{4}{|l|}{ Cultivar } \\
\hline 'Picual' & $55.8 \mathrm{a}$ & $30.5 \mathrm{a}$ & $62.1 \mathrm{ab}$ \\
\hline 'Arbequina' & $47.6 \mathrm{a}$ & $28.0 \mathrm{a}$ & $75.9 \mathrm{ab}$ \\
\hline 'Frantoio' & - & $31.5 \mathrm{a}$ & $51.8 \mathrm{~b}$ \\
\hline 'Sikitita' & - & $23.2 \mathrm{a}$ & $93.2 \mathrm{a}$ \\
\hline Interaction soil $x$ cultivar ${ }^{2}$ & NS & NS & NS \\
\hline $\mathrm{CV}(\%)^{3}$ & 42.9 & 39.8 & 39.9 \\
\hline
\end{tabular}

${ }^{1}$ Means within columns and factors followed by different letters are significantly different at $p \leq 0.05$ by Tukey's test. ${ }^{2}$ NS $=$ Non-significant ${ }^{3}$ Coefficient of variation.

\section{Discussion}

Nitrogen overfertilization is a common practice in many agricultural systems. In the olive, and in other crops, it has been demonstrated that this practice had no significant effects on yield, fruit characteristic, or growth $[5,16]$, but results in negative effects on the tree and the crop, in environmental damage, and in increases costs [6,7]. The cause could be the small amounts of nitrogen removed annually, around $54.4 \mathrm{~kg} \cdot \mathrm{ha}^{-1}$ including fruit and pruning removal [17], and also that in many orchards nitrogen balance is usually positive [18]. These data suggest that the need for nitrogen fertilization in olive orchards is low, and that the application of small amounts of nitrogen fertilizers results in nitrogen overfertilization.

The development of a sustainable fertilization practice requires the reduction of fertilizer inputs and their efficient application. One sustainable strategy proposed is to use or develop cultivars with high nitrogen uptake efficiency. Genetic variability has been observed in other crops [12,13] but nothing is known in the olive. The results obtained in the present work indicate that in the olive there are also differences among cultivars in the efficiency of nitrogen uptake. Two of the most cultivated varieties in Spain for oil production, 'Picual' and 'Arbequina', and 'Manzanilla de Sevilla', one of the most important for table olives, are included between the cultivars with high NUE in this work, together with the Greek cultivar 'Koroneiki' and the Italian 'Frantoio'. This is the clearest conclusion of the present work, suggesting that cultivar selection for a new orchard could also be based on the efficiency of nitrogen uptake in order to reduce the use of nitrogen fertilizers. On the other hand, the relationship between nitrogen uptake efficiency and nitrogen content of the plant is not clear, although cultivars which accumulate more nitrogen usually were those with high uptake efficiency. But these parameters are not related to plant vigour, indicating that those plants that grow more do not have to be the most efficient in accumulate or uptake nitrogen.

One of the objectives of this work was to study if the type of soil affects nitrogen uptake efficiency. The results showed that soil type does not affect this parameter and that no interaction between soil type and cultivar was observed. The results indicated that the differences observed in this work correspond only to genetic variation.

Author Contributions: Conceptualization, R.F.-E.; methodology, R.F.-E., F.A.-B. and S.A.-L.; formal analysis, F.A.-B. and S.A.-L.; investigation, F.A.-B., S.A.-L.; writing-original draft preparation, R.F.-E.; supervision, R.F.-E.; project administration, R.F.-E.; funding acquisition, R.F.-E. All authors have read and agreed to the published version of the manuscript. 
Funding: This research was financed by the Spanish Ministry of Science and Innovation, Project No. AGL2011-25752, and European Regional Development Funds (ERDF).

Conflicts of Interest: The authors declare no conflict of interest.

\section{References}

1. Weinbaum, S.A.; Johnson, R.S.; de Jong, T.M. Causes and consequences of overfertilization in orchards. HortTechnology 1992, 2, 112-121. [CrossRef]

2. Faqi, W.; Haibin, L.; Baosheng, S.; Jian, W.; Gale, W.J. Net primary production and nutrient cycling in an apple orchard-annual crop system in the Loess Plateau, -China: A comparison of Qinguan apple, Fuji apple, corn and millet production systems. Nutr. Cycl. Agroecosyst. 2008, 81, 95-105. [CrossRef]

3. Albornoz, F. Crop responses to nitrogen overfertilization. Sci. Hortic. 2016, 205, 79-83. [CrossRef]

4. Swarbreck, S.M.; Wang, M.; Wang, Y.; Kindred, D.; Sylvest er-Bradley, R.; Shi, W.; Singh, V.; Bentley, A.R.; Griffiths, H.A. Roadmap for lowering crop nitrogen requirement. Trends Plant Sci. 2019, 24, 892-904. [CrossRef] [PubMed]

5. Fernández-Escobar, R.; Marin, L.; Sánchez-Zamora, M.A.; García-Novelo, J.M.; Molina-Soria, C.; Parra, M.A. Long-term effects of $\mathrm{N}$ fertilization on cropping and growth of olive trees and on $\mathrm{N}$ accumulation in soil profile. Eur. J. Agron. 2009, 31, $223-232$. [CrossRef]

6. Erel, R.; Kerem, Z.; Ben-Gal, A.; Dag, A.; Schwartz, A.; Zipori, I.; Basheer, L.; Yermiyahu, U. Tree N status is a key factor for oil quality. J. Agric. Food Chem. 2013, 61, 11261-11272. [CrossRef] [PubMed]

7. Fernández-Escobar, R. Olive nutritional status and tolerance to biotic and abiotic stresses. Front. Plant Sci. 2019, $10,1151$. [CrossRef] [PubMed]

8. Shear, C.B.; Faust, M. Nutritional ranges in deciduous tree fruits and nuts. Hortic. Rev. 1980, 2, 142-163.

9. Benton Jones, J. Soil testing and plant analysis: Guides to the fertilization of horticultural crops. Hortic. Rev. 1985, 7, 1-68.

10. Fernández-Escobar, R.; Parra, M.A.; Navarro, C.; Arquero, O. Foliar diagnosis as a guide to olive fertilization. Span. J. Agric. Res. 2009, 7, 212-223. [CrossRef]

11. Fernández-Escobar, R.; Antonaya-Baena, M.F.; Sánchez-Zamora, M.A.; Molina-Soria, C. The amount of nitrogen applied and nutritional status of olive plants affect nitrogen uptake efficiency. Sci. Hortic. 2014, 167, 1-4. [CrossRef]

12. Zebarth, B.J.; Tai, G.; Tarn, R.; de Jong, H.; Milburn, P.H. Nitrogen use efficiency characteristics of commercial potato cultivars. Can. J. Plant Sci. 2004, 84, 589-598. [CrossRef]

13. Sorgona, A.; Abenavoli, M.R.; Gringeri, P.G.; Cacco, G. A comparison of nitrogen use efficiency definitions in Citrus rootstocks. Sci. Hortic. 2006, 109, 389-393. [CrossRef]

14. Getahun, B.B.; Kassie, M.M.; Visser, R.G.F.; van der Linden, C.G. Genetic diversity of potato cultivars for nitrogen use efficiency under contrasting nitrogen regimes. Potato Res. 2019. [CrossRef]

15. Dumas, J.B.A. Procedes de l'analyse organic. Ann. Chim. Phys. 1831, 247, 198-213.

16. Bustan, A.; Avni, A.; Yermiyahu, U.; Ben-Gal, A.; Riov, J.; Erel, R.; Zipori, I.; Dag, A. Interactions between fruit load and macroelement concentrations in fertigated olive (Olea europaea L.) trees under arid saline conditions. Sci. Hortic. 2013, 152, 44-55. [CrossRef]

17. Fernández-Escobar, R.; Sánchez-Zamora, M.A.; García-Novelo, J.M.; Molina-Soria, C. Nutrient removal from olive trees by fruit yield and pruning. HortScience 2015, 50, 1-5. [CrossRef]

18. Fernández-Escobar, R.; García-Novelo, J.M.; Molina-Soria, C.; Parra, M.A. An approach to nitrogen balance in olive orchards. Sci. Hortic. 2012, 135, 219-226. [CrossRef] 